\title{
Effects of Different Mulching Materials and Planting Distance on Selected Soil Properties of Organic Farms Planted with Orthosiphon stamineus
}

\author{
${ }^{1}$ Department of Land Management, Faculty of Agriculture, UPM, 43400 Serdang, Selangor, Malaysia. \\ ${ }^{2}$ Department of Biology, Faculty of Science, UPM, 43400 Serdang, Selangor, Malaysia. \\ ${ }^{3}$ School of Agriculture, Faculty of Science and Technology, University College Yayasan Pahang, Malaysia. \\ ${ }^{4}$ School of Environmental and Natural Resources Science, UKM, 43600 Bangi, Selangor, Malaysia. \\ ${ }^{5}$ Department of Agriculture Technology, Faculty of Agriculture, UPM, 43400 Serdang, Selangor, Malaysia. \\ ${ }^{6}$ Department of Plant Protection, Faculty of Agriculture, UPM 43400 Serdang, Selangor, Malaysia.
}

N.A.A. Hamid ${ }^{1}$, S.R. Keeren², A.B. Zahidah³, K.S. Daljit1,*, A. Norulhuda4, M.M. Farrah' ${ }^{5}$, Z. Dzarifah ${ }^{6}$

\section{ARTICLE DETAILS}

\section{Article history:}

Received 01 August 2019

Accepted 21 August 2019

Available online 10 September 2019

\section{Keywords:}

Organic Farming

Orthosiphon stamineus

Planting Distance

Mulching Materials

\begin{abstract}
A B S T R A C T
A field study was carried out to determine the impact of mulching and planting distance on the growth of Orthosiphon stamineus, soil properties and also to observe the changes in $\mathrm{pH}$ and EC of soil in response to mulching and planting distance. The experiment was carried out at Ladang 16, Faculty of Agriculture UPM. Factorial Randomized Complete Block Design (RCBD) was incorporated with four replicates for each of the four treatments. The four treatments consisted of mulching, non-mulching, planting distance of $30 \mathrm{~cm} \times 30 \mathrm{~cm}$ and planting distance of $45 \mathrm{~cm} \times 45 \mathrm{~cm}$. After eight weeks of planting, the plants were harvested while soil $\mathrm{pH}$ and $\mathrm{EC}$ were measured on a weekly basis throughout the planting period. Results showed that application of biochar and usage of mulching materials and suitable planting distance does helps to maintain the soil $\mathrm{pH}$ and electrical conductivity (EC) at the suitable range for crop growth. The level of the acidity of the soil is in the range of 5.3 to 6.61 which is considered appropriate for $O$. stamineus. As for influence of planting distance, it is best to give longer time for 0 . stamineus grows. It is recommended that more planting distance and types of mulching materials to be used to grow $O$. stamineus.
\end{abstract}

\section{Introduction}

Orthosiphon stamineus (Family: Lamiaceae) can grow up to $1.5 \mathrm{~m}$, exhibiting opposite pairs of leaf arrangement, simple, glabrous, lanceolate leaf blade with serrate margin and green in colour [1]. The white flower species produced rhomboid shapes in leaves without coloured spots, acuminate apex, abtuse base, and green venation. Zaharah and Salbiah [2] found that Orthosiphon stamineus is suitable to be cultivated in any type of soil including sandy soils like BRIS and tin tailings. The plant needs an average monthly rainfall of $180-200 \mathrm{~cm}$ to grow well and irrigation should be provided during dry season. Orthosiphon stamineus leaves were used as remedy for kidney stones, diabetes, capillary and circulatory disorders.

Mulching is a loose covering or sheet of organic material that is spread on top of the soil as a protective layer. It can be either derived from organic waste like paddy straw or inorganic materials like plastic mulching. Mulching has proven to be an effective method in reducing water and soil loss rates. A good layer of mulch will help to preserve moisture and suppress weed germination. Mulch also enhances root and increases maize grain crop yield by increasing plant $\mathrm{N}$-uptake efficiency, decreasing the losses of nitrogen discharge and improving nutrient preservation over non-mulched plots [3]. Mulching involves maintaining a permanent or semi-permanent protective cover on the soil surface that can be composed of different materials such as vegetative residues, biological geo-textiles, gravel and crushed stones

\subsection{Plastic Mulching}

Plastic mulching has been used widely in the production of vegetables since 1950s [4]. Plastic mulches are used to protect seedlings and shoots through insulation and preventive excessive evaporation. In semiarid areas of the Loess Plateau in northwest China, plastic mulching is an important material to improve crop productivity $[5,6]$. The different colour of plastic mulch determines its energy-radiating behaviour and its influence on the microclimate around the vegetable plant.

\subsection{Straw Mulching}

Straw mulch is also used in many developed countries including America and Australia where it helps to improve soil properties such as soil moisture retention ability, prevent wind erosion, weed control and nutrient retention. Sonsteby et al. [7] reported that application of straw mulch and grass mulch significantly increased the available phosphorus and potassium in the soil. Nutrients which are being released from biodegradation of these materials add as soil supplement thus improve fertility for plant growth.

\subsection{Planting Distance}

Good planting distance gives the right plant density, which allows for optimum yield production. Adequate plant distance in combination with plant per unit area also will give a good yield. Planting distance also plays important roles in the performance, production and consequently the yield of medicinal and aromatic plants which in turn affect the farm income and food security [8]. Acosta and Lergh [9] found that a planting distance of $40 \mathrm{~cm}$ and cutting height of $20-25 \mathrm{~cm}$ gave the best yields of Orthosiphon stamineus.

\subsection{Biochar}

Biochar is the product of thermal degradation of organic materials in the absence of air known as pyrolysis and used as a soil amendment. Soil amendment with biochar is globally seen as an excellent source to improve soil fertility by enhance soil aggregation, water holding capacity, soil aggregate stability [10]. Biochar can also mitigate climate change because it contains highly condensed aromatic structures that resist decomposition in soil and thus can effectively sequester a portion of the applied carbon [11,12]. 


\subsection{Chicken Manure}

Animal manures such as chicken dung contribute nutrients to the soil such as nitrogen, phosphorus and potassium. The usage of chicken dung as a soil amendment can help to increase organic matter content and improve soil structure. Composted chicken manure can also increase soil biota and improve soil water holding capacity. Zaharah and Salbiah [2] recommended that the optimum fertilizer of Orthosiphon stamineus is 5 $t /$ ha usage of organic fertilizer such as chicken manure in alluvium soil and $10 \mathrm{t} / \mathrm{ha}$ in BRIS soil for six months.

\subsection{Organic Fertilizer}

Organic fertilizers are farm waste comprising mainly of crop residues, animal manure, compost, green manure and residues from the processing of plant, animal and sewage sludge products. Many researchers have reported on the benefits of organic fertilizer such as enhancement in soil biological activity which improves nutrient mobilization from organic and chemical sources, promote root growth due to better soil structure, improves soil water retention and improves soil organic matter content.

Bokashi is a plant-based fertilizer used in this study as a source of nutrient for plant growth. Bokashi is made up using a Japanese technique where organic matter is fermented with the addition of efficient microorganisms $[13,14]$. Besides that, the addition of bokashi improves nutrient concentration in the soils of the experimental site and improved survival and growth rates of pine seedlings from local and commercial nurseries. The objective of this study was to determine the effect of different mulching types and planting distance on selected soil properties of Orthosiphon stamineus.

\section{Experimental Methods}

\subsection{Experimental Layout and Treatment}

This experiment was conducted at Farm 16, Faculty of Agriculture Universiti Putra Malaysia. Soil in the plot was Bungor series, which is classified as kaolinitic and isohyperthermic. About 5.0 tonne/ha of biochar and 2.5 tonne/ha chicken dung were used as soil amendments and were applied one week before planting. Bokashi fertilizer at $300 \mathrm{~kg} \mathrm{~N} /$ ha was also used as a nutrient source for plant growth. The Orthosiphon stamineus variety that was used for planting is MOS 1 . O. stamineus which was cultivated via stem cutting. Silver shine plastic mulching was used to cover the beds for treatment with mulching and without plastic mulching (nonmulching). The planting distance used was $45 \mathrm{~cm} \times 45 \mathrm{~cm}$ and $30 \mathrm{~cm} \times 30$ $\mathrm{cm}$. The experiment was laid out in RCBD and arranged in a factorial experiment with 2 types of mulching $\times 2$ types of planting distances with 4 replications each (Table 1 ).

Table 1 Experimental layout for Orthosiphon stamineus experiment

\begin{tabular}{ll}
\hline Treatment details & Label \\
\hline Mulching \& planting distance $30 \mathrm{~cm} \times 30 \mathrm{~cm}$ & M30 \\
Non-mulching \& planting distance $30 \mathrm{~cm} \times 30 \mathrm{~cm}$ & NM30 \\
Mulching \& planting distance $45 \mathrm{~cm} \times 45 \mathrm{~cm}$ & M45 \\
Non-mulching \& planting distance $45 \mathrm{~cm} \times 45 \mathrm{~cm}$ & NM45 \\
\hline
\end{tabular}

\subsection{Soil Analyses and Plant Growth Measurement}

The soil samples were collected before planting and every week for 8 weeks. The fresh soil samples were air-dried and sieved through $2.0 \mathrm{~mm}$ sieve prior to analysis. Soil texture (clay, silt and clay fraction) was determined using universal pipette method. Bulk density and particle density were determined according to the procedure described by Gupta [15] for disturbed soil samples. Soil moisture content was determined using gravimetric method. Soil $\mathrm{pH}$ in water was extracted using 1:2.5 ratio of soil to distilled water and was read by calibrated $\mathrm{pH}$ meter [16; 17]. Soil Electrical conductivity was determined using EC meter with ratio 1:2.5 soil to water. Kjeldahl method was used for determination of total nitrogen (N). Total carbon (C) was determined using carbon analyzer.

The exchangeable bases of potassium $\left(\mathrm{K}^{+}\right)$, calcium $\left(\mathrm{Ca}^{2+}\right)$ and magnesium $\left(\mathrm{Mg}^{2+}\right)$ were extracted using $1 \mathrm{M}$ ammonium acetate $\left(\mathrm{NH}_{4} \mathrm{OAc}\right)$ solution at $\mathrm{pH} 7$ and the concentration were read using automatic absorption spectrophotometer (AAS) [18]. Available phosphorus (P) was extracted using Bray 2 solution consisting of ammonium fluoride $\left(\mathrm{NH}_{4} \mathrm{~F}\right)$ and $0.1 \mathrm{M}$ hydrochloric acid $(\mathrm{HCl})$ [19]. The height growth (basal to the shoot tip) of the Orthosiphon stamineus plants were measured fortnightly throughout the study period using measuring tape for eight weeks. Fresh and dry weight of plants were recorded after harvesting using weighing balance.

\subsection{Statistical Analyses}

A one-way analysis of variance (ANOVA) followed by post-hoc Tukey test $(\mathrm{p}<0.05)$ was used to analyse and compare the results obtained between treatments. The SPSS version 16.00 was used for the data analyses.

\section{Results and discussion}

\subsection{Physico-Chemical Properties of Soil at Organic Plot}

Table 2 shows the physico-chemical properties analysed before planting. The result showed that the soil pH of the organic plot at Farm 16 was acidic (4.62). The moisture content was low (1.83\%). The total carbon, cation exchange capacity (CEC), total nitrogen, calcium, magnesium, potassium and available phosphorus was also low. The soil had high porosity (67.84\%). Bulk density reading was quite low and the soil texture contained high clay.

Table 2 Physico-chemical properties of the soil at organic plot

\begin{tabular}{ll}
\hline Parameter & Results \\
\hline Soil texture (\%) & \\
$\quad$ Clay & 62.99 \\
$\quad$ Sand & 30.51 \\
$\quad$ Silt & 6.51 \\
Bulk density $\left(\mathrm{g} \mathrm{cm}^{-3}\right)$ & 0.85 \\
Porosity $(\%)$ & 67.84 \\
Moisture content $(\%)$ & 1.80 \\
Soil pH & 4.62 \\
Soil EC $\left(\mathrm{dSm}^{-1}\right)$ & 0.12 \\
Total N $(\%)$ & 0.17 \\
Total C $(\%)$ & 2.05 \\
Available P $(\mathrm{ppm})$ & 31.36 \\
CEC $\left(\mathrm{cmol}_{\mathrm{cgg}}-1\right)$ & 8 \\
Ca $\left(\mathrm{cmol}_{\mathrm{cg}}{ }^{-1}\right)$ & 0.04 \\
Mg $\left(\mathrm{cmol}_{\mathrm{c}} \mathrm{kg}^{-1}\right)$ & 0.02 \\
$\mathrm{~K}\left(\mathrm{cmol}_{\left.\mathrm{c} \mathrm{kg}^{-1}\right)}\right.$ & 0.14 \\
\hline
\end{tabular}

\subsubsection{Soil $p H$}

Figs. 1-4 show the results of soil $\mathrm{pH}$ for six weeks for the different treatments. The acidity level for every treatment for period of six weeks is at the range of 5.35 to 6.61 . The range is considered acceptable and suitable for the growth of 0 . stamineus. Application or organic materials like chicken manure or cow dung might increase the acidity of the soil as those materials will decompose. However, the application of biochar in the treatments able kept the $\mathrm{pH}$ range at suitable limits.

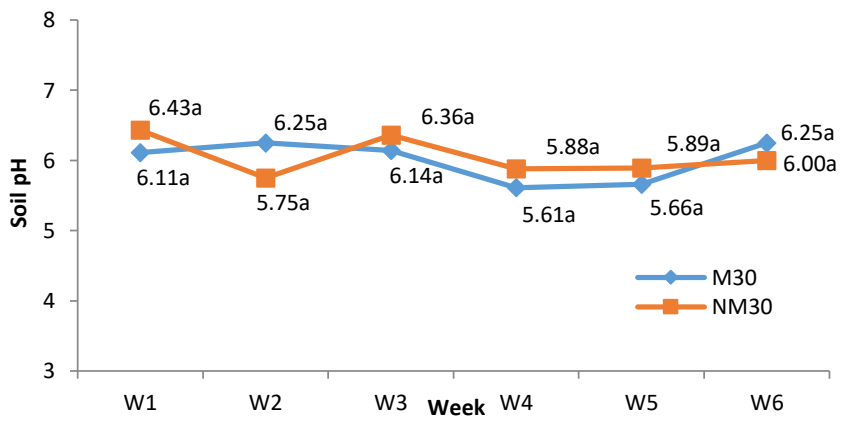

Fig. $1 \mathrm{pH}$ of soil samples for six weeks. Note: M30: Mulching with planting distance $30 \mathrm{~cm} \times 30 \mathrm{~cm}$, NM30: Non-mulching with planting distance $30 \mathrm{~cm} \times 30 \mathrm{~cm}$

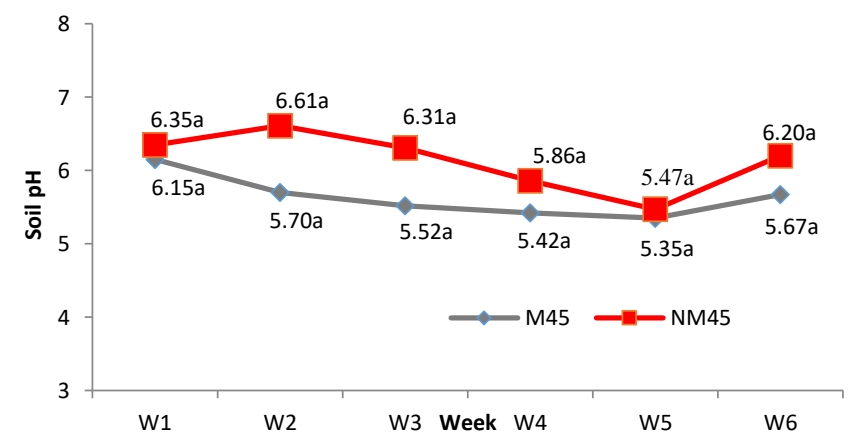

Fig. $2 \mathrm{pH}$ of soil samples for six weeks. Note: M45: Mulching with planting distance $45 \mathrm{~cm} \times 45 \mathrm{~cm}$, NM45: Non-Mulching with planting distance $45 \mathrm{~cm} \times 45 \mathrm{~cm}$ 


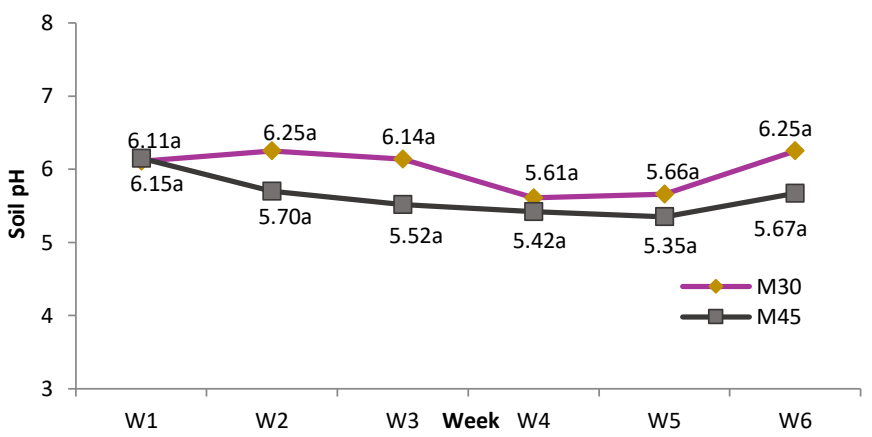

Fig. $3 \mathrm{pH}$ of soil samples for six weeks. Note: M30: Mulching with planting distance $30 \mathrm{~cm} \times 30 \mathrm{~cm}, \mathrm{M} 45$ : Mulching with planting distance $45 \mathrm{~cm} \times 45 \mathrm{~cm}$

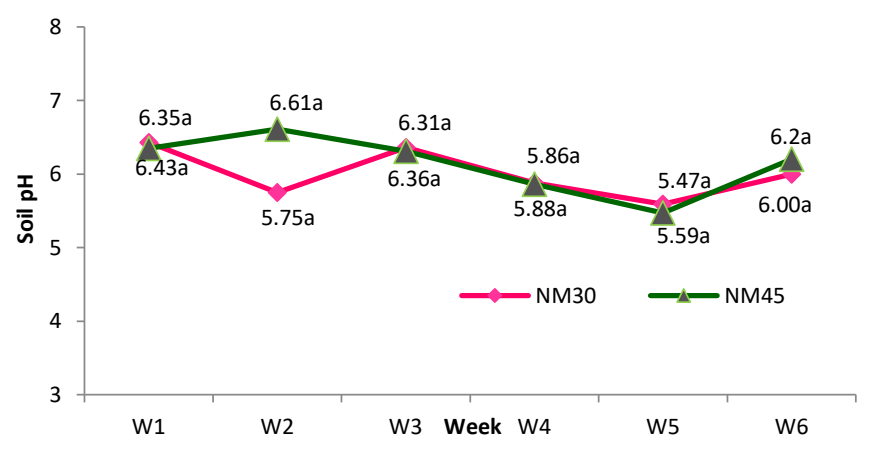

Fig. $4 \mathrm{pH}$ of soil samples for six weeks. Note: NM30: Non-mulching with planting distance $30 \mathrm{~cm} \times 30 \mathrm{~cm}$, NM45: Non-Mulching with planting distance $45 \mathrm{~cm} \times 45 \mathrm{~cm}$

\subsubsection{Soil Electrical Conductivity}

Figs. 5-8 show the soil EC reading for six weeks under different treatments. The results showed that there were no significant differences among the treatments and range of soil EC was between $0.25-0.55 \mathrm{dSm}-$ 1. It was found treatment M45 had decreases in soil EC, from the first week to the sixth week. Chaudhry et al. [20] stated that using mulching can decrease soil electrical conductivity compared to non-mulching treatment. The result showed the range of soil EC was in non-saline class.

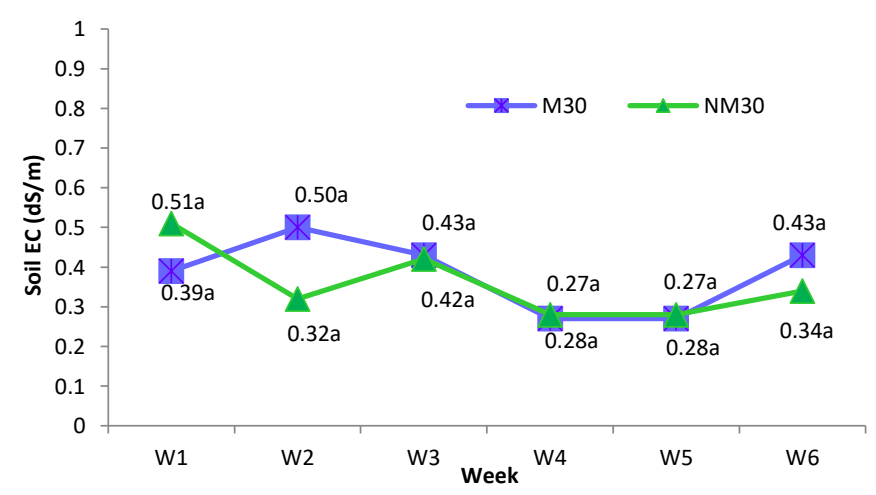

Fig. 5 Electrical Conductivity reading of soil samples for six weeks at $\mathrm{P} \leq 0.05$. Note: M30: Mulching with planting distance $30 \mathrm{~cm} \times 30 \mathrm{~cm}$, NM30: Non-mulching with planting distance $30 \mathrm{~cm} \times 30 \mathrm{~cm}$

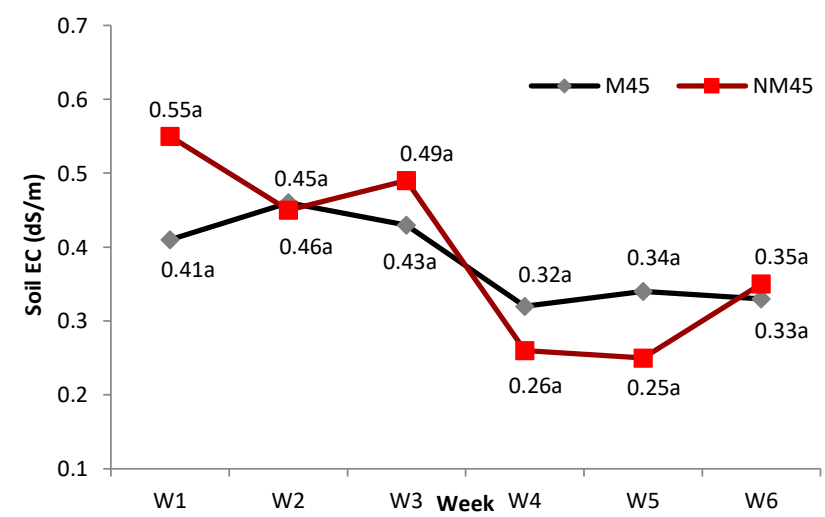

Fig. 6 Electrical conductivity reading of soil samples for six weeks at $P \leq 0.05$. Note: M45: Mulching with planting distance $45 \mathrm{~cm} \times 45 \mathrm{~cm}$, NM45: Non-Mulching with planting distance $45 \mathrm{~cm} \times 45 \mathrm{~cm}$

https://doi.org/10.30799/jnpr.080.19050202

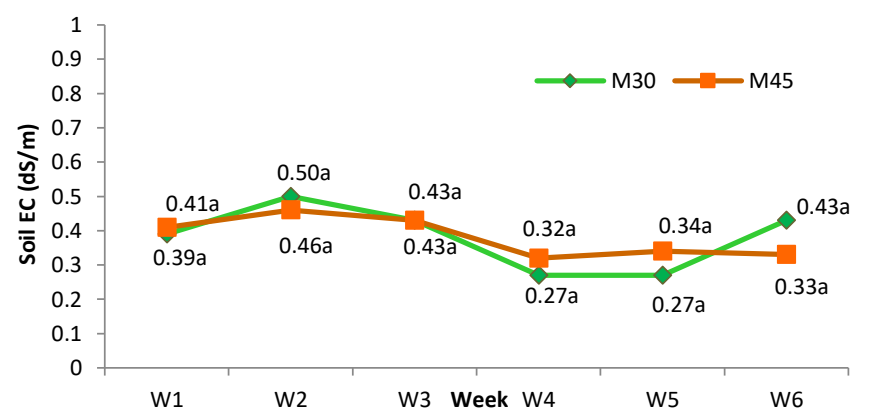

Fig. 7 Electrical conductivity reading of soil samples for six weeks. Note: M30: Mulching with planting distance $30 \mathrm{~cm} \times 30 \mathrm{~cm}$, M45: Mulching with planting distance $45 \mathrm{~cm} \times 45 \mathrm{~cm}$

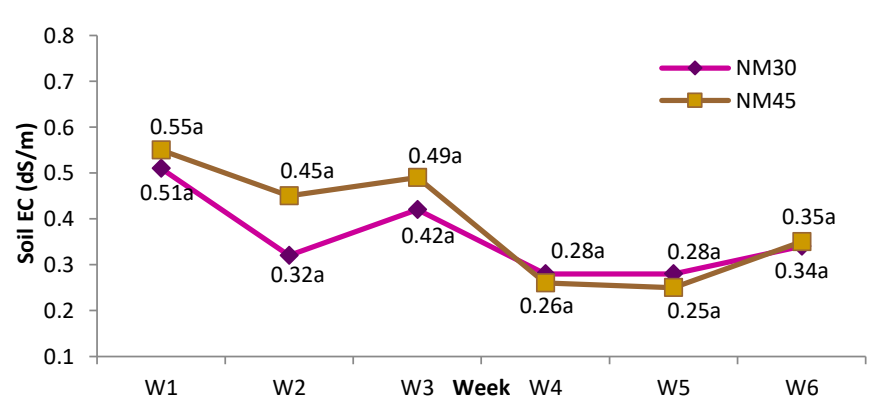

Fig. 8 Electrical Conductivity reading of soil samples for six weeks at $\mathrm{P} \leq 0.05$. Note: NM30: Non-mulching with planting distance $30 \mathrm{~cm} \times 30 \mathrm{~cm}$, NM45: Non-Mulching with planting distance $45 \mathrm{~cm} \times 45 \mathrm{~cm}$

\subsubsection{Cation Exchange Capacity and Exchangeable Bases}

Table 3 shows that there are no significant results of CEC, exchangeable bases $(\mathrm{K}, \mathrm{Ca}$ and $\mathrm{Mg}$ ) for all treatments after six weeks. The highest level of CEC recorded was in treatment NM30 $\left(9.3 \mathrm{cmol}_{\mathrm{c}} \mathrm{kg}^{-1}\right)$. The Bungor series and the CEC of the series is usually less than $16 \mathrm{cmol}_{\mathrm{c}} \mathrm{kg}^{-1}$. Treatment M30 showed the highest exchangeable $\mathrm{K}\left(0.85 \mathrm{cmol}_{\mathrm{c}} \mathrm{kg}^{-1}\right)$. The calcium content in the soil is quite low and the highest reading was $0.60 \mathrm{cmol}_{\mathrm{c} \mathrm{kg}}{ }^{-1}$ (NM45). The treatment M45 showed the highest reading of exchangeable Mg (1.68 $\mathrm{cmol}_{\mathrm{c}} \mathrm{kg}^{-1}$ ) as compared to the other four treatments. Longer duration on the application of plastic mulching might help increment or retention of CEC as the plastic mulching protect the soil from leaching process.

Table 3 Effect of mulching and planting distance on CEC and exchangeable bases

\begin{tabular}{llllll}
\hline $\begin{array}{l}\text { Treatment } \\
(\text { TRT })\end{array}$ & $\begin{array}{l}\text { Distance } \\
\text { (DIS) }\end{array}$ & $\begin{array}{l}\mathrm{CEC}\left(\mathrm{cmol}_{\mathrm{c}}\right. \\
\left.\mathrm{kg}^{-1}\right)\end{array}$ & $\begin{array}{l}\mathrm{K}\left(\mathrm{cmol}_{\mathrm{c}}\right. \\
\left.\mathrm{kg}^{-1}\right)\end{array}$ & $\begin{array}{l}\mathrm{Ca}\left(\mathrm{cmol}_{\mathrm{c}}\right. \\
\left.\mathrm{kg}^{-1}\right)\end{array}$ & $\begin{array}{l}\mathrm{Mg}\left(\mathrm{cmol}_{\mathrm{c}}\right. \\
\left.\mathrm{kg}^{-1}\right)\end{array}$ \\
\hline M & $30 \times 30$ & $9.12 \pm 2.53 \mathrm{a}$ & $0.85 \pm 4.77 \mathrm{a} 0.58 \pm 0.20 \mathrm{a}$ & $1.46 \pm 0.06 \mathrm{a}$ \\
NM & $30 \times 30$ & $9.30 \pm 4.55 \mathrm{a}$ & $0.63 \pm 1.47 \mathrm{a}$ & $0.58 \pm 0.25 \mathrm{a}$ & $1.51 \pm 0.04 \mathrm{a}$ \\
M & $45 \times 45$ & $8.53 \pm 3.64 \mathrm{a}$ & $0.50 \pm 1.18 \mathrm{a}$ & $0.46 \pm 0.44 \mathrm{a}$ & $1.68 \pm 0.07 \mathrm{a}$ \\
NM & $45 \times 45$ & $8.27 \pm 3.90 \mathrm{a}$ & $0.64 \pm 3.07 \mathrm{a} 0.60 \pm 0.05 \mathrm{a}$ & $1.14 \pm 0.01 \mathrm{a}$ \\
\hline TRT & & $\mathrm{ns}$ & $\mathrm{ns}$ & $\mathrm{ns}$ & $*$ \\
DIS & & $*$ & $*$ & $\mathrm{~ns}$ & $\mathrm{~ns}$ \\
TRT*DIS & & $\mathrm{ns}$ & $\mathrm{ns}$ & $\mathrm{ns}$ & $\mathrm{ns}$ \\
\hline
\end{tabular}

Note for all subsiquent tables: From each factors, means within a column followed by the same letter are not significantly different as indicated by Honest Significant Difference at $P \leq 0.05$. *is significant at $P \leq 0.05$, ns is not significant. M: mulching, NM: non-mulching, planting distance: $30 \mathrm{~cm} \times 30 \mathrm{~cm}$ and $45 \mathrm{~cm} \times 45 \mathrm{~cm}$

There was no significant difference at $\mathrm{P} \leq 0.05$ found for all soil total carbon, nitrogen and available $\mathrm{P}$ among the treatments (Tables 4). Increase in soil nitrogen under mulching might be due to addition of organic material.

Table 4 Soil total carbon, nitrogen and available phosphorus

\begin{tabular}{lllll}
\hline Treatment (TRT) & Distance (DIS) & $\mathrm{C}(\%)$ & $\mathrm{N}(\%)$ & $\mathrm{P}(\mathrm{ppm})$ \\
\hline $\mathrm{M}$ & $30 \times 30$ & $2.71 \pm 0.26 \mathrm{a}$ & $0.21 \pm 1.98 \mathrm{a}$ & $130.55 \pm 4.30 \mathrm{a}$ \\
$\mathrm{NM}$ & $30 \times 30$ & $2.54 \pm 0.21 \mathrm{a}$ & $0.20 \pm 1.10 \mathrm{a}$ & $114.80 \pm 3.37 \mathrm{a}$ \\
$\mathrm{M}$ & $45 \times 45$ & $2.21 \pm 0.06 \mathrm{a}$ & $0.19 \pm 0.85 \mathrm{a}$ & $85.10 \pm 1.66 \mathrm{a}$ \\
NM & $45 \times 45$ & $2.38 \pm 0.04 \mathrm{a}$ & $0.18 \pm 0.61 \mathrm{a}$ & $118.65 \pm 1.70 \mathrm{a}$ \\
\hline TRT & $\mathrm{ns}$ & $\mathrm{ns}$ & $\mathrm{ns}$ \\
DIS & & $*$ & $\mathrm{~ns}$ & $\mathrm{~ns}$ \\
TRT*DIS & & $\mathrm{ns}$ & $\mathrm{ns}$ & $\mathrm{ns}$ \\
\hline
\end{tabular}

\subsubsection{Bulk Density, Moisture Content and Porosity}

Table 5 shows the result of the treatments on bulk density, porosity and moisture content. It was found that the treatment did not show any significant difference on the soil physical properties. Bulk density was 
significantly higher, showed by treatment NM30 $\left(0.92 \mathrm{gcm}^{-3}\right)$. Bulk density is a soil parameter that is used to quantify soil compactness. Mbah et al. [21] reported that high bulk density results in reduced water infiltration into the soil, reduced aeration and poor root penetration, resulting in reduction of crop yield. The results showed that the moisture content was very low and not significant among the treatments. Since, the plot was at the field, the moisture content might have variation according to the amount of water that was received by plant. Narrow planting distance had higher moisture content compared with wider planting distance. Treatment M30, M45 and NM45 showed the similarly higher mean of soil porosity compared to NM30. Soils with high porosity are good for crop because it provides more pore space for roots to establish. Suitable porosity level helps the plant growth where the roots can grow well in the soil and can uptake the nutrients.

Table 5 Soil bulk density, moisture content and porosity

\begin{tabular}{lllll}
\hline $\begin{array}{l}\text { Treatment } \\
(\text { TRT })\end{array}$ & $\begin{array}{l}\text { Distance } \\
(\mathrm{DIS})\end{array}$ & $\begin{array}{l}\text { Bulk density } \\
\left(\mathrm{gcm}^{-3}\right)\end{array}$ & $\begin{array}{l}\text { Moisture } \\
\text { content (\%) }\end{array}$ & Porosity (\%) \\
\hline M & $30 \times 30$ & $0.85 \pm 0.01 \mathrm{a}$ & $1.91 \pm 0.08 \mathrm{a}$ & $67.83 \pm 0.48 \mathrm{a}$ \\
NM & $30 \times 30$ & $0.92 \pm 0.01 \mathrm{a}$ & $1.84 \pm 0.09 \mathrm{a}$ & $65.36 \pm 0.71 \mathrm{a}$ \\
M & $45 \times 45$ & $0.88 \pm 0.01 \mathrm{a}$ & $1.65 \pm 0.06 \mathrm{a}$ & $66.80 \pm 0.55 \mathrm{a}$ \\
NM & $45 \times 45$ & $0.91 \pm 0.01 \mathrm{a}$ & $1.68 \pm 0.03 \mathrm{a}$ & $65.90 \pm 0.19 \mathrm{a}$ \\
\hline TRT & & $*$ & $\mathrm{~ns}$ & $*$ \\
DIS & & $\mathrm{ns}$ & $*$ & $\mathrm{~ns}$ \\
TRT*DIS & & $\mathrm{ns}$ & $\mathrm{ns}$ & $\mathrm{ns}$ \\
\hline
\end{tabular}

3.2 Effect of Mulching and Planting Distance on Orthosiphon stamineus Growth

\subsubsection{Plant Height}

Table 6 shows the plant height of 0 . stamineus for all treatments significantly different at $\mathrm{P} \leq 0.05$ with different planting distance. In this experiment, narrow distance exhibited the highest plant height and increased plant density compared with wider distance. Ibeawuchi et al. [8] reported that the okra spaced $30 \mathrm{~cm}$ within the row was significantly taller than other okra plants spaced otherwise. This may be attributed to the close spacing of $30 \mathrm{~cm}$ along the row which made the crops to be crowded, possibly because of intra competition for light and other growth resources.

Table 6 Height increment of 0 . stamineus by 8 weeks

\begin{tabular}{lll}
\hline Treatment (TRT) & Distance (DIS) & Height $(\mathrm{cm})$ \\
\hline M & $30 \times 30$ & $73.23 \pm 0.58 \mathrm{a}$ \\
NM & $30 \times 30$ & $73.03 \pm 1.01 \mathrm{a}$ \\
Mean DIS $(30 \mathrm{~cm})$ & & $73.63 \mathrm{a}$ \\
M & $45 \times 45$ & $65.38 \pm 1.91 \mathrm{a}$ \\
NM & $45 \times 45$ & $65.45 \pm 3.02 \mathrm{a}$ \\
Mean DIS $(45 \mathrm{~cm})$ & & $65.41 \mathrm{~b}$ \\
TRT & & $\mathrm{ns}$ \\
DIS & $*$ \\
TRT*DIS & $\mathrm{ns}$ \\
\hline
\end{tabular}

Table 7 Average yield fresh weight, dry weight, roots fresh weight and dry weight

\begin{tabular}{|c|c|c|c|c|c|}
\hline $\begin{array}{l}\text { Treatment } \\
\text { (TRT) }\end{array}$ & $\begin{array}{l}\text { Distance } \\
\text { (DIS) }\end{array}$ & $\begin{array}{l}\text { YFW } \\
(\mathrm{Kg})\end{array}$ & $\begin{array}{l}\text { YDW } \\
\text { (Kg) }\end{array}$ & $\begin{array}{l}\text { RFW } \\
(\mathrm{Kg})\end{array}$ & $\begin{array}{l}\text { RDW } \\
\text { (Kg) }\end{array}$ \\
\hline $\bar{M}$ & $30 \times 30$ & $\begin{array}{l}18.60 \pm \\
1.23 \mathrm{a}\end{array}$ & $\begin{array}{l}2.99 \pm \\
0.20 \mathrm{a}\end{array}$ & $\begin{array}{l}0.40 \pm \\
0.06 \mathrm{a}\end{array}$ & $\begin{array}{l}0.10 \pm \\
0.01 \mathrm{a}\end{array}$ \\
\hline NM & $30 \times 30$ & $\begin{array}{l}20.55 \pm \\
2.08 \mathrm{a}\end{array}$ & $\begin{array}{l}3.29 \pm \\
0.33 \mathrm{a}\end{array}$ & $\begin{array}{l}0.42 \pm \\
0.05 \mathrm{a}\end{array}$ & $\begin{array}{l}0.09 \pm \\
0.01 \mathrm{a}\end{array}$ \\
\hline M & $45 \times 45$ & $\begin{array}{l}10.55 \pm \\
1.88 \mathrm{a}\end{array}$ & $\begin{array}{l}1.69 \pm \\
0.30 \mathrm{a}\end{array}$ & $\begin{array}{l}0.53 \pm \\
0.04 \mathrm{a}\end{array}$ & $\begin{array}{l}0.12 \pm \\
0.01 \mathrm{a}\end{array}$ \\
\hline NM & $45 \times 45$ & $\begin{array}{l}8.38 \pm \\
2.03 a\end{array}$ & $\begin{array}{l}1.34 \pm \\
0.33 \mathrm{a}\end{array}$ & $\begin{array}{l}0.59 \pm \\
0.04 \mathrm{a}\end{array}$ & $\begin{array}{l}0.14 \pm \\
0.01 \mathrm{a}\end{array}$ \\
\hline \multicolumn{2}{|c|}{ Mean DIS $(30 \mathrm{~cm})$} & $19.58 \mathrm{a}$ & $3.14 \mathrm{a}$ & $0.41 \mathrm{~b}$ & $0.09 \mathrm{~b}$ \\
\hline \multicolumn{2}{|c|}{ Mean DIS $(45 \mathrm{~cm})$} & $9.46 \mathrm{~b}$ & $1.52 \mathrm{~b}$ & $0.56 \mathrm{a}$ & $0.13 \mathrm{a}$ \\
\hline \multicolumn{2}{|l|}{ TRT } & ns & ns & ns & ns \\
\hline \multicolumn{2}{|l|}{ DIS } & $*$ & * & * & $*$ \\
\hline \multicolumn{2}{|l|}{ TRT*DIS } & ns & ns & ns & ns \\
\hline
\end{tabular}

\subsubsection{Biomass of Yield and Roots of Orthosiphon stamineus}

Table 7 shows the fresh and dry weight of the yield and roots of Orthosiphon stamineus. Even though there is no significant difference, treatments NM30 showed the highest biomass yield of $20.55 \mathrm{~kg}$ fresh weight and $3.29 \mathrm{~kg}$ dried weight. Treatments NM45 on Orthosiphon stamineus shows the highest biomass of roots where the $0.59 \mathrm{~kg}$ fresh weight and $0.14 \mathrm{~kg}$ dried weight. Wider planting distance contributes to the elongation and increment of the roots.

\section{Conclusion}

Using mulching materials on the growing bed for 0 . stamineus does help in retaining selected soil properties. As for planting distance, suitable distance will allow the roots of the $O$. stamineus to grow well. However, further study using other type of mulching and also planting distance should be conducted to find the best approach to grow 0 . stamineus. It is recommended to use biochar as soil amendment to grow $O$. stamineus as application on biochar does helps in maintaining the soil acidity level which is suitable for 0 . stamineus growth.

\section{Acknowledgement}

This work was financed by UPM Grant - IPM/2016/9484900. We would like to express our gratitude to Mr. Sahar and other staff who helped us with the fieldwork.

\section{References}

[1] A. Abdu, N. Aderis, H. Abdul-Hamid, N.M. Majid, S. Jusop, et al., Using Orthosiphon stamineus B. for phytoremediation of heavy metals in soils amended with sewage sludge, Am. J. Appl. Sci. 8(4) (2011) 323-331.

[2] A. Zaharah, H. Salbiah, Population density of Misai Kucing (Orthosiphon stamineus) grown on BRIS soil, Curr. Trends Perspect.: Proceeding of the Seminar on Medicinal and Aromatic Plants (2005) 374-382

[3] M.S. Aulakh, T.S. Khera, J.W. Doran, Kuldip-Singh, Bijay-Singh, Yields and nitrogen dynamics in a rice-wheat system using green manure and inorganic fertilizer, Soil Sci. Soc. Am. J. 64(5) (2000) 1-11.

[4] W.J. Lamont, Plastics: Modifying the microclimate for the production of vegetable crops, Horticult. Technol. 15(3) (2005) 477-481.

[5] F.M. Li, J. Wang, J. Xu, H.L. Xu, Productivity and soil response to plastic film mulching durations for spring wheat on entisols in the semiarid Loess Plateau of China, Soil Tillage Res. 78(1) (2004) 9-20.

[6] J. Wang, X. Fu, U.M. Sainju, F. Zhao, Soil carbon fractions in response to straw mulching in the Loess Plateau of China, Biol. Fert. Soils 54(4) (2018) 423-436.

[7] A. Sǿnsteby, A. Nes, F. Mage, Effects of bark mulch and NPK fertilizer on yield, leaf nutrient status and soil mineral nitrogen during three years of strawberry production, Acta Agricult. Scand. B - Soil \& Plant Sci. 54(3) (2004) 128-134.

[8] I.I. Ibeawuchi, E. Matthews-Njoku, M.O. Ofor, C.O. Anyanwu, V.N. Onyia, Plant spacing, dry matter accumulation and yield of local and improved maize cultivars, Jour. Am. Sci. 4(1) (2008) 11-20.

[9] L. Acosta, G. Lergh, Effect of planting distance and cutting height on yield of Orthosiphon stamineus (Benth), Revista Cubana de Farmacia 18 (1984) 409 414.

[10] J. Lehmann, M.C. Rillig, J.E. Thies, C. Masiello, W.C. Hockaday, D. Crowley, Biochar effects on soil biota - A review, Soil Biol. Biochem. 43(9) (2011) 18121836

[11] B. Fungo, J. Lehmann, K. Kalbitz, M. Tenywa, M. Thiongo, H. Neufeldt, Emissions intensity and carbon stocks of a tropical Ultisol after amendment with Tithonia green manure, urea and biochar, Field Crops Res. 209 (2017) 179-188.

[12] F.X. Wang, S.Y. Feng, X.Y. Hou, S.Z. Kang, J.J. Han, Potato growth with and without plastic mulch in two typical regions of Northern China, Field Crops Res. 110(2) (2009) 123-129.

[13] S. Xiaohou, T. Min, J. Ping, C. Weiling, Effect of EM Bokashi application on control of secondary soil salinization, Water Sci. Eng. 1(4) (2008) 99-106.

[14] P.F. Jaramillo-López, M.I. Ramírez, D.R. Pérez-Salicrup, Impacts of Bokashi on survival and growth rates of Pinus pseudostrobus in community reforestation projects, Jour. Environ. Manage. 150 (2015) 48-56.

[15] P.K. Gupta, Soil, Plant, water and fertilizer analysis, Agribios, India, 2007.

[16] D.S. Karam, A. Arifin, O. Radziah, J. Shamshuddin, H. Abdul-Hamid, et al., Evaluation of soil biological properties of 9- and 15-year-old stands in the oil palm plantation in Perak, Malaysia, Afr. J. Agri. Res. 8(29) (2013) 3904-3910.

[17] K.S. Rajoo, A. Abdu, H. Abdul-Hamid, D.S. Karam, S. Jusop, et al., Assessment of heavy metals uptake and translocation by Aquilaria malaccensis planted in soils containing sewage sludge, Am. J. Appl. Sci. 10(9) (2013) 952-964.

[18] A. Arifin, D.S. Karam, J. Shamshuddin, N.M. Majid, O. Radziah, et al., Proposing a suitable soil quality index for natural, secondary and rehabilitated tropical forests in Malaysia, Afr. J. Biotechnol. 11(14) (2012) 3297-3309.

[19] R.H. Bray, L.T. Kurtz, Determination of total, organic and available forms of phosphorus in soils, Soil Sci. 59(1) (1945) 39-46.

[20] M.R. Chaudhry, A.A. Malik, M. Sidhu, Mulching impact on moisture conservation - soil properties and plant growth, Pak. J. Water Resour. 8(2) (2004) 1-8.

[21] C.N. Mbah, J.N. Nwite, C. Njoku, L.M. Ibeh, T.S. Igwe, Physical properties of an Ultisols under plastic film and no-mulches and their effect on the yield of maize, World J. Agri. Sci. 6(2) (2010) 160-165. 